\title{
Learning to read: A third perspective
}

\author{
Eve Gregory ${ }^{1}$
}

Published online: 25 September 2017

(C) The Author(s) 2017. This article is an open access publication

\begin{abstract}
How children learn to read is a controversial matter. Since the teaching of literacy has always been a major purpose of schooling, pedagogy and teaching methods have generally framed research and practice. Psychologists and linguists have played a major role in determining what we mean by "literacy learning". Although they disagree on whether children should start with phonics and work toward meaning or vice versa, both limit the task to the cognitive and linguistic capabilities of the individual. In this article, I argue for an extension of this paradigm, whereby sociocultural theories are given equal value with both psychological and linguistic perspectives. Using examples from ethnographic studies in London, I show how children learn complex texts by becoming members of communities they wish to join. Through playing, rehearsing, modelling, and practice, they learn the value of literacy alongside the cognitive and linguistic skills needed for learning to take place.
\end{abstract}

Keywords Sociocultural theories · Play $\cdot$ Mediators $\cdot$ Rehearsal $\cdot$ Prolepsis $\cdot$ Learning to read

"Learning to read" means different things to different people at different times and in different places. To many poorer children and their families in nineteenth-century Britain, it meant learning by heart the Bible or other religious texts at Sunday school. The method of memorizing holy texts continues to this day, since such texts are often couched in an unfamiliar language or use difficult and formal vocabulary. For a Muslim child, learning to

I would like to dedicate this article to the memory of Brian Street, who had a powerful influence on all my work throughout many years. This was the last paper Brian invited me to write and his ideas emerge strongly throughout the piece.

Eve Gregory

e.gregory@gold.ac.uk

1 Goldsmiths College, University of London, 8 Lewisham Way, New Cross, London SE14 6NW, UK 
read the Holy Qur'an means learning by heart a text in an unknown language or dialect to produce a beautiful recitation. Hindu children will also "read" the ancient language of Sanskrit in this way. In contrast, classroom teachers in the United Kingdom often focus on teaching phonics as a precursor to understanding the meaning of a text or relating it to children's lives. Both interpretations of reading are very different from what takes place during reading a novel for pleasure, texting friends, or reading semaphore or music. These are just a few of the myriad of ways that "learning to read" is understood today.

Amidst these, there are possibly two truisms: Intellectually, learning to read always involves the learning of symbolization - the interpreting of symbols of some sort; and pedagogically, how the teaching and learning of symbolization best happens awakens strong feelings and debate by teachers, parents, and politicians. Therefore, the question remains: How do children best begin learning to read, and how might educators most effectively teach them? Here, I first examine existing psychological and linguistic perspectives informing curricula in UK schools. I then present examples from longitudinal and ethnographic research in children's homes and communities, to argue for the inclusion of a third perspective-one using sociocultural theories to explain how young children might set about reading with confidence and success.

\section{"Simple" versus "complex" methods: Psychological and linguistic perspectives}

How do existing research studies explain how children learn to read and how teachers might teach them? These studies reveal no consensus of opinion. The relationship between reading, language, and the mind has long been a question of debate. In his revolutionary book The Psychology and Pedagogy of Reading, published in New York in 1908, Edward Huey claims reading to be "a highly complex task, which involves very many of the most intimate workings of the mind" (p. 6). Since then, educators and researchers have put forth contradictory ideas on exactly how these "workings of the mind" take place and how complex or simple they are.

The traditional debate (sometimes referred to as "the great debate" by Chall in 1967, and explained fully by Adams [1995]) that took place throughout the twentieth century was between those holding "bottom-up" and "top-down" perspectives on how children learn to read. Such specialist jargon can be confusing, but it is important to understand these and other key terms, as they reflect contrasting theories that have been influential in informing beginning-reading tuition throughout the twentieth and into the twenty-first century.

\section{One perspective: Bottom-up theory}

At its simplest, studies from psychology (Rose 2006; Stuart and Coultheart 1988) underpin the bottom-up or "simple" theory, as do claims that learning to read proceeds from the particular to the general: from the smallest unit of meaning (individual sound, or phoneme) to the largest (knowledge of the world, or semantic knowledge; and knowledge of the structure of language, or syntactic knowledge). Those supporting the bottom-up theory of reading maintain that learning requires a reconstruction of the sound forms of a word on the basis of its graphic representation, whereby understanding arises as a result of correct recreation of the sound form of words. In other words, decoding sounds and pronouncing words are seen as means to gaining understanding. Early-reading tuition based entirely on the bottom-up theory stresses the need to teach children first to match phonemes (sounds) 
to graphemes (symbols), which are gradually built up into words (lexis) and larger units of meaning. This is sometimes referred to simply as a "phonic approach" to beginning reading.

\section{A second perspective: Top-down theory}

The top-down theory is a reversal of the bottom-up view and emerges from linguistics (Goodman 1996; Smith 2012). It posits that understanding proceeds from the general to the particular; from a knowledge of the language of the text, as well as a general knowledge of the culture, to predicting and reading individual words and letters. Those supporting the top-down theory believe that the recognition of printed or written symbols serves only as stimuli for the recall of meanings built up through past experience and for the reconstruction of new meanings through the manipulation of concepts that the reader already grasps. Early-reading tuition influenced by this view emphasizes teaching beginner readers to use existing semantic and syntactic knowledge in order to be able to select from alternatives and predict the written word. This is sometimes referred to simply as a "topdown" approach.

In the twenty-first century, educators generally acknowledge that both decoding (bottom-up) and meaning-making (top-down) are essential components in fluent reading. Researchers and teachers from both sides of the debate also agree that some systematic phonics training is beneficial for all children as they begin to learn to read. However, they substantially disagree on the following: How much phonics training should be given, at what age, and what type? How much training in meaning-making should be given, at what age, and what type? And crucially, should decoding and meaning-making be split up and taught separately, or are they intrinsically interdependent in the process of learning to read?

Theories and consequent policies on beginning-reading instruction have been in constant flux from the last three decades of the twentieth century until the present day. During the 1970s, look-and-say (whole-word recognition) was the most common approach, followed in Britain in the 1980s by the apprenticeship approach (guided book reading alongside a more experienced reader). By the end of the twentieth century, official policy in Britain was to use an eclectic approach (a combination of whole texts with guided reading, phonics, and sight-word recognition) similar to the whole-language approach in the United States. However, during the early years of the twenty-first century, official policies in both the United States and Britain have swung sharply in favour of the bottomup advocates in the reading debate, some of whom claim that phonics training should be taught "first and fast" (Miskin 2005, p. 20). Beginning-reading policies in Britain during the first decade of the twenty-first century are informed by the "simple view of reading", a model (described below) originally put forward by Gough and Turner, and taken up in the US by the National Reading Panel in 2000.

So how should early decoding or word recognition be developed? The "simple view" proposes restricting reading instruction during initial stages entirely to the use of a synthetic-phonics programme. Synthetic phonics starts with single letters and the sounds they represent (Lloyd 2003). After the teacher has taught a few letters and sounds (including one or two vowels), children look at simple words containing those letters and attempt to produce a sound for each letter (no digraphs are used at first), then to blend the sounds to make a word with normal word pronunciation. The teacher shows letters in all positions in words from the start. Generally, the first letters will be $s, a, t, i, p, n$ and the first digraphs $s h$, th, $a i, o a$. The aim is for children to blend an increasing number of 
words as their word-to-sound correspondences increase-for example, at, dog, hen, spot, hill-and for this learning to take place quickly so that children can work words out for themselves. In this way, advocates claim, the programme "empowers children" (Miskin 2005, p. 14), since, if they decode effortlessly, all their energies can go into working out the content of the book.

Accordingly, during these early stages teachers should introduce children only to reading books containing sounds and digraphs they have already learned (i.e., only books belonging to the relevant published scheme) in order not to confuse them or demotivate them if they see words they cannot decode. During the second stage of the programme, teachers introduce children to digraphs (two letters making one sound) and the children practice blending them into regular words using examples, such as, $b$-oa-t, sl-ee-p, and sh$o u-t$. During a third stage, teachers present less-regular words, usually at the rate of two or three per week. If children pronounce a word inaccurately, their teacher asks them to look for the irregular part; e.g., $d o$, where the $o$ is an $o o$ sound). The key strategy is that of blending sounds, gradually moving from the smallest sound to building up to the word itself.

But those supporting this view are not the only discussants in the debate; a second, and equally strong, group exists for whom phonics teaching is only one strategy amongst others (and synthetic phonics only one type of phonics teaching amongst others), and for whom meaning and decoding are intrinsically linked. These researchers and practitioners are from a number of countries in the English-speaking world. They share little in common apart from a deep-seated belief that there is no simple solution to learning to read, nor can there be a "universal method" (Adams 1995, p. 23). After a comprehensive review and analysis of both basic and applied research on the topic, Marilyn Jager Adams (Center for the Study of Reading, University of Illinois-Urbana-Champaign) argues strongly in Beginning to Read (1995) that decoding (or phonics) and meaning (or context) are inextricably linked and should be taught simultaneously in beginning-reading programmes. Adams views phonemic awareness - by which she includes not only a knowledge of sound patterns but also phonological awareness and a knowledge of spelling (orthographic) patterns-is an essential base upon which to build and that meaning is an inherent part of the reading process, too. She concludes: "[Children] must become aware of the structure of language, from sentences and words to phonemes. And, most important, they must develop a basic understanding of the forms and functions of text and of its personal value to their own lives" (Adams 1995, p. 422).

\section{A third perspective: The personal value of reading}

The third perspective on learning to read that I propose in this article relates to the "personal value" referred to by Adams, but understood differently. Specifically, I am referring to Adams' reference to interpreting reading from a sociocultural viewpoint (Street 1993, 1995). Accordingly, I argue that it is not the value of the text itself that needs to be important to children, but rather the value of reading as an essential part of belonging or becoming a member of a specific cultural practice. How else might we explain how young children learn to read long or complex texts, whose phonics or actual meaning they are unable to unravel with relative ease? In this perspective, the value of reading for the child is put in the centre, not at the periphery. The focus of how learning takes place switches from the teacher's methods to the child's control over his or her learning. This perspective is grounded in Vygotskian theories that view mental processes as social in origin and mediated through interaction with individuals using cultural 
artefacts and practices that have evolved over time (Daniels, Cole, and Wertsch 2007; Vygotsky 1978). By playing out important practices of their culture, children become expert practitioners themselves (Gregory, Long, and Volk 2004). Viewed in this way, the personal value attached to reading by a child is intimately linked with the personal importance of membership in a cultural practice or group for a child.

In his argument for the recognition of cultural psychology, Michael Cole refers to "mind as interiorized culture and culture as exteriorized mind" (1998, p. 292), and illustrates further the implications of what has become known as a "sociocultural approach" to viewing learning. Integral to this are the concepts of prolepsis and synergy. By prolepsis, I refer to the process whereby caregivers (often parents or grandparents) project into the child's future by drawing upon their own experiences, thus promoting both knowledge and continuity of understandings between generations. This might happen in everyday activities, but is particularly strong where languages or faith practices are involved. These are the areas where the older generation close to the child clearly has expertise and acts as a mediator of cultural practices. Other work using sociocultural theory recognizes prolepsis, but at the same time illustrates a synergy between generations, whereby the older members of a culture learn equally from the younger either by the act of teaching or by acknowledging and learning from new knowledge that might inform existing practices. Use of digital and internet learning are examples of this (Flewitt, Messer, and Kucirkova 2015; Gregory, Arju, Jessel, Kenner, and Ruby 2007; Kenner, Ruby, Jessel, Gregory, and Arju 2007). Taking this perspective, questions for teachers to ask will be: In which social and cultural practices does reading play an important and integral part for the child? Where do these take place, how often, and using what methods or interaction patterns? How can we analyze the nature of learning and detail the literacy skills needed in order to participate? Who might mediate children's learning and how does this take place? What might we as educators learn from this knowledge, for our classroom practice? Below, I explore three examples from recent ethnographic studies undertaken in children's homes and communities and discuss how a sociocultural perspective explains how early reading takes place. Finally, I show how personal value is integral to the activities across all examples and its relationship to the cultural practices in which each activity is embedded.

I draw these examples from three ethnographic studies on young children's learning: with siblings, with grandparents, and in their faith settings. (The Economic and Social Research Council funded these three projects, from which I draw the data: Gregory (1999-2000); Kenner, Gregory, and Jessel (2003-2004); and Gregory, Jessel, Kenner, and Lytra (2009-2013). They are illustrative of similar studies described by other authors (for example, Volk with Acosta 2004; Drury 2007; Pahl and Rowsell 2010; Marsh and Bishop 2012), where researchers conducted longitudinal work with families in their homes. The excerpts below show children whose parents or grandparents were born outside Britain and who are familiar with other languages at home. The participants themselves collected the data for excerpts 1 and 2; researchers gave children in the siblings project small tape-recorders and the children taped themselves without the presence of adults; researchers well known to the participants filmed grandmothers and their grandchildren. The researcher for excerpt 3 (from the BeLiFS project, www.belifs. co.uk) provided the data, using a prayer recited by children in both the faith and home settings. 


\section{Excerpts from the field}

\section{Play: Siblings and the value of school learning}

The first excerpt shows 11-year-old Wahida "playing school" with Sayeda, her 8-year-old sister. The children live in East London and were born in Britain of parents who came from Bangladesh. Like a number of schools in the neighbourhood, theirs receives almost all its pupils from Sylhet, a region in northeast Bangladesh. Both girls attend community language classes to learn Bengali literacy and Qur'anic classes to learn to read the Qur'an in classical Arabic. However, when playing school, they always use English. This excerpt comes near the middle of an hour-long tape made at home in which Wahida "teaches" her sister numeracy, spelling, science, and poetry, and listens to her read. Although living in an area where people have strong London accents, the girls' voices echo the standard English of their teachers.

Wahida Sayeda

1: Well done! Only two wrong. Now we're going to do homophones. Who knows what's a homophone is? No one? OK. I'll tell you one and then you're going to do some by yourselves. Like watch-one watch is your time watch, like what's the time, watch. And another watch is I'm watching you, I can see you. OK? So, Sayeda, you wrote some in your book, haven't you? Can you tell me some please. Sayeda, can you only give me three please.

2: Oh I have to give five.

3: No, Sayeda, we haven't got enough time. We've only another five minutes to assembly. And guess who's going to do assembly- Miss Kudija.

4: OK.

5: OK? So tell me one.

7: Yeah

6: Son is the opposite of daughter ...

8: and sun is ... um ... its shines on the sky so bright.

9: Well done! That's one correct one.

The next one?

11: The last one is ?

10: The cell means you go ... to jail ...in prison ... you're going to prison and another sell means the selling money ... they are giving money.

12: Hear. Hear is you're hearing something... people are telling you something and here is come here, come.

13: Well done! Now you can go to assembly. Sayeda, line up in order. Otherwise you'll come back and do lines. So remember your order. OK? Well done, Sayeda, you're in your correct order and Miss Kudija is going to take you down because I have to do some more things. 
Wahida proudly models herself on the teacher, a person in whose knowledge she trusts. Sayeda is her competent pupil. Vygotsky (1978) argues that through sociodramatic play, children become a head taller than in real life, and we see clearly how this takes place. Crucially, we also see how synergies take place whereby both children learn from each other. Wahida, the older child, learns through practicing what she already knows about homophones and through modelling the task to be taught (turn 1). Sayeda has recently learned the concept of a homophone in her classroom and needs the reinforcement and confidence given through further teaching by her older sister. Both children have internalized the language patterns, skills, and knowledge needed for literacy, and we see how they value and identify themselves as readers.

\section{Prolepsis and synergy: The value of learning between grandparents and grandchildren}

The following example illustrates how prolepsis and synergies take place in an intergenerational exchange. Razia is in her fifties and was born in Chittagong, Bangladesh, where she still lives. Her three sons and two daughters, however, have moved to New York, Canada, and London, and she spends much of her time traveling to visit her grandchildren. Here she is in London reading a Chora (Bengali religious rhyme or prayer) with her grandson, six-year-old Sahil. The poem chosen on this occasion is about how a child will plan his day from the moment he wakes up and how he will take his teaching from the respected wisdom from the elders in the community.

Razia leads by reading a few words from the text; her tone of voice becomes more serious, and this is taken to signal a more formal mode of learning. Sahil repeats, taking great care in how he sounds the words: where sound comes from, such as the throat and nose, which part of the mouth he uses, and even how he forms his cheeks will all have a bearing on how effective his pronunciation in Bengali is judged to be. Razia demonstrates, corrects, and supports Sahil continually as the session proceeds. The cycle of Razia reading and Sahil repeating continues; this is a traditional teaching pattern in Bangladesh, especially with new or unfamiliar material. Although Sahil's Bengali is good enough to allow him to understand parts of the story, there are also unfamiliar words, and he perseveres with his grandmother's help (Jessel, Gregory, Arju, Kenner, and Ruby 2004, pp. 18, 21).

Sahil: Akhane ki bole? [What does it mean here?]

Razia: Konta? [Which one?]

On other occasions, Sahil takes the lead, such as with computer activities. He is confident when using the mouse and is familiar with both the game to be played and the purpose of the computer in partnering him in the game. Sahil has set up the card game Solitaire on the computer:

Sahil: Asho akhane. [Come here.]

Razia: Oita ami akhono khelte parbo na tomi khelo. [I cannot play that yet, you play.]

Prior to Sahil's instruction, Razia was unfamiliar with how to play Solitaire.

Razia: Amake bolo tomi ki ki korso. [Tell me what you have done.]

... Dekhi to tomi. [Let me have a look.]

... Erm bolo na Dadu ... bolo na. [Erm tell Granny ... tell me.]

Sahil: Aita akhan rakhte ... [This one put ...] 
Razia appears to take an interest and watches Sahil, who tries to explain what he is doing as he repositions the cards on the computer screen.

Sahil: Aita khotai rakhi, akhane? [Where shall I put this, here?]

Razia: Hmm ...

Sahil: Na aikhane okhane airokom kore. [No, this there, like this.]

Razia: Dadu tho computer khelte pari na tomi dekhai dou. [Granny does not know

how to play computer, you show me.]

Sahil: Akhane akhane [Here, here]

. . . Ami jani ... tomi koro. [I know ... you do it.]

Razia then reaches for the mouse and begins to move it while attempting to press the centre scroll wheel. As she does this, Sahil places his hand on top of hers, indicating that she should click the left mouse button. Sahil then continues to guide Razia's hand. Sahil continues to take the lead and the transcript of the dialogue suggests that he feels confident in this role:

Sahil: Akhane koro, na akhan ... akhan koro. [Put it here, no here ... now do it.]

In the first part of the excerpt, Razia conveys to her grandson important cultural, linguistic, and literacy knowledge. Sahil does not understand much of the actual meaning of the text, which is in formal literary Bengali rather than the Chittagong dialect that he knows. Yet, her reading tone, rhythm, and repetition reiterate how special this is; it clearly has great value for him, drawing him closer to both his grandmother and the faith he has yet to learn. The second part of the excerpt switches to show Sahil as expert in the use of the computer mouse. Like with the siblings, taking the role of teacher becomes an important part of learning.

\section{Prayer: Learning through faith}

The Hail Mary Prayer (or Zdrowaś Maryjo in Polish) is a prayer to Mary, the Mother of God, and is of special religious, cultural, and historical significance for Polish Catholics.

\begin{tabular}{ll}
\hline Zdrowaś Maryjo & Hail Mary \\
Zdrowaś Maryjo, taski petna & Hail Mary, full of grace \\
Pan z toba. & The Lord is with you. \\
Błogosławionaś ty między niewiastami & Blessed you are among women \\
I błogostawiony owoc żywota Twojego, & And blessed is the fruit of your womb, \\
Jezus & Jesus \\
Świeta Maryjo, matko Boża, & Holy Mary, the Mother of God, \\
Módl się za nami grzesznymi, & Pray for us sinners, \\
Teraz i w godzine śmierci naszej. Amen. & Now and in the hour of our death. Amen.
\end{tabular}

Polish children from Catholic families learn the Hail Mary prayer from their parents when they say prayers at home, usually at bedtime. It is a moment of calmness and intimacy, where children reflect on the day and its events. Children are encouraged to pray using their own words; for example, to apologize for what they have done wrong, to thank God 
for all the good things that happened to them, and also to ask for help in difficult or important situations.

At the Polish school attached to a Polish church, the Hail Mary Prayer, together with the Lord's Prayer and the Prayer to the Holy Spirit, is said each Saturday morning at assembly time. The priest stands on the stage and the children, parents, and teachers turn toward him and say the three prayers in unison, in Polish. It is a very powerful shared statement of cultural and linguistic belonging, as the words of the prayer sound immediately familiar to everyone present.

The Hail Mary Prayer introduces the Polish child to the concept of conversation in a literary form with a special language. The prayer itself has a strong rhythm and sounds like a poem. It introduces the child to the Old Polish verb forms zdrowaś (be greeted) and błogostawionaś (be blessed), and to an Old Polish word niewiasta (woman). These words are no longer used in everyday language, therefore increasing children's linguistic awareness of Old Polish. The prayer and its significant cultural, historical, and political context—passed on to children by their parents-reinforce the importance of the figure of Mother in children's lives.

After baptism, the First Holy Communion is a very important event in the life of a Polish Catholic child. Children preparing for their First Holy Communion memorize the Hail Mary, along with other catechism prayers and the commandments, when the rosary is said. They must learn the Hail Mary text, which is not easy to remember; this requires them to draw heavily on their memorizing abilities.

For Polish Catholics, the Hail Mary Prayer combines biblical and religious aspects with specifically Polish cultural, historical, and political ones. Its learning is multimodal, as text, spoken word, and images interweave in the children's minds. Its recitation takes place individually, in intimate family groups, and with peers and adults within the Polish community. It fosters cultural and linguistic belonging and unifies the community. The child sees herself as a part of a family (Holy Trinity) where Mary, a woman, has an important part to play (Gregory et al. 2013, p. 243).

The text introducing this excerpt is typical of the level of difficulty tackled by children across the four faith groups with whom our research team worked for nearly four years (www.belifs.co.uk). Nevertheless, all the children managed to recite the texts, and through tuition, learned of its meaning for their faith. Children were able to tackle literacy at a level far higher than they could in formal classrooms where tuition followed either a bottom-up or top-down approach. I argue that they were able to do this through strong motivation to belong to a group that likewise wanted strongly to include its younger members. This type of personal value is unique in that children regarded their learning as not for themselves or their families, but for God-which situates meaning in the performance of a beautiful recitation or other symbolic act rather than in the content of the text itself.

\section{Concluding thoughts}

Today, a considerable number of studies reveal a variety of young children's home literacy practices, especially digital literacies in play and virtual worlds (Flewitt, Messer, and Kucirkova 2015; Marsh and Bishop 2013; Wohlwend 2010). All of these show a variety of literacy skills and knowledge gained by young children without official classroom teaching. Yet, paradoxically, Spencer, Knobel, and Lankshear (2013) claim that there "remains a relative absence of ethnographic-type investigations of young children's everyday 
literacy practices" (p. 134). Their words highlight my argument that existing theories of early-literacy learning are intrinsically situated in pedagogy, in classroom teaching rather than in children's home learning. It is true that ethnographic studies into what actually happens in children's homes show learning to be unpredictable and thus beyond the control of teachers and policymakers. My aim in this article, however, has been to show the importance of including the third perspective - to give it equal weight with both psychological and linguistic theories of reading. It is only within a more complex framework that we can fully acknowledge, do justice to, and learn from the invisible worlds beyond our reach in schools.

Open Access This article is distributed under the terms of the Creative Commons Attribution 4.0 International License (http://creativecommons.org/licenses/by/4.0/), which permits unrestricted use, distribution, and reproduction in any medium, provided you give appropriate credit to the original author(s) and the source, provide a link to the Creative Commons license, and indicate if changes were made.

\section{References}

Adams, M. T. (1995). Beginning to read: Thinking and learning about print. Cambridge, MA: MIT Press. Bakhtin, M. (1986). Speech genres and other late essays. Austin, TX: University of Texas Press.

Chall, J. (1967). The great debate. New York, NY: McGraw-Hill.

Cole, M. (1998). Can cultural psychology help us think about diversity? Mind, Culture and Activity, 5(4), 291-304.

Daniels, H., Cole, M., \& Wertsch, J. V. (Eds.) (2007). The Cambridge companion to Vygotsky. Cambridge: Cambridge University Press.

Drury, R. (2007). Young bilingual learners at home and school: Researching multilingual voices. Stoke-onTrent, Staffordshire: Trentham Books.

Fairclough, N. (1989). Language and power (2nd ed.). Harlow, Essex: Longman.

Flewitt, R., Messer, D., \& Kucirkova, N. (2015). New directions for literacy in a digital age: The iPad. Journal of Early Childhood Literacy, 15(3), 289-310.

Goodman, K. (1996). On reading. Portsmouth, NH: Heinemann.

Gregory, E. (1999-2000). Siblings as mediators of literacy in 3 communities. Research project funded by the Economic and Social Research Council. RES 000-22-2487.

Gregory, E., Arju, T., Jessel, J., Kenner, C., \& Ruby, M. (2007). Snow White in different guises: Intergenerational and intercultural exchanges between grandparents and young children at home in East London. Journal of Early Childhood Literacy, 7(1), 5-25.

Gregory, E., Choudhury, H., Ilankuberan, A., Kwapong, A., \& Woodham, M. (2013). Practise, performance and perfection: Learning sacred texts in four faith communities. International Journal for the Sociology of Language, 220, 27-48.

Gregory, E., Jessel, J., Kenner, C., \& Lytra, V. (2009-2013). Becoming literate in faith settings: Language and literacy learning in the lives of new Londoners. Research project funded by the Economic and Social Research Council. RES 062-23-1613.

Gregory, E., Long, S., \& Volk, D. (Eds.) (2004). Many pathways to literacy: Young children learning with siblings, grandparents, peers and communities. London: Routledge.

Huey, E. (1908). The psychology and pedagogy of reading. New York, NY: Macmillan.

Jessel, J., Gregory, E., Arju, T., Kenner, C., \& Ruby, M. (2004). Children and their grandparents at home: A mutually supportive context for learning and linguistic development. English Quarterly, 36(4), 16-23.

Kenner, C. Gregory, E., \& Jessel, J. (2003-2004). Intergenerational learning between children and grandparents in East London. Research project funded by the Economic and Social Research Council. RES 000-22-0131.

Kenner, C., Ruby, M., Jessel, J., Gregory, E., \& Arju, T. (2007). Intergenerational learning between children and their grandparents in East London. Journal of Early Childhood Research, 5(3), 219-243.

Lloyd, S. (2003). Synthetic phonics: What is it? Reading Reform Foundation Newsletter, 50(Spring), 25-27.

Marsh, J., \& Bishop, J. C. (2012). Rewind and replay? Television and play in the 1950s/1960s and 2010s. International Journal of Play, 1(3), 279-291. 
Marsh, J., \& Bishop, J. C. (2013). Challenges in the use of social networking sites to trace potential research participants. International Journal of Research \& Method in Education. doi:10.1080/1743727X.2013. 820642.

Miskin, R. (2005). Contribution to Teaching children to read. Eighth report of session 2004-2005, House of Commons Education and Skills Committee. London: The Stationery Office.

Pahl, K., \& Rowsell, J. (2010). Artifactual literacies: Every object tells a story. New York, NY: Teachers College Press.

Rose, J. (2006). Independent review of the teaching of early reading. Nottingham: Department for Education and Skills.

Simpson, P. (1993). Language, ideology and point of view. New York, NY: Routledge.

Smith, F. (2012). Understanding reading: A psycholinguistic analysis of reading and learning to read (6th ed.). New York, NY: Routledge.

Spencer, T., Knobel, M., \& Lankshear, C. (2013). Researching young children's out-of-school literacy practices. In J. Larson \& J. Marsh (Eds.), The Sage handbook of early childhood literacy (2nd ed.). London: Sage.

Street, B. V. (Ed.) (1993). Cross-cultural approaches to literacy. Cambridge: Cambridge University Press.

Street, B. V. (1995). Social approaches to literacy in development, ethnography and education. New York, NY: Routledge.

Stuart, M., \& Coltheart, M. (1988). Does reading develop in a sequence of stages? Cognition, 30, $139-181$.

Volk, D., \& Acosta, M. (2004). Mediating networks for literacy learning: The role of Puerto Rican siblings. In E. Gregory, S. Long, \& D. Volk (Eds.), Many pathways to literacy: Young children learning with siblings, grandparents, peers and communities. London: Routledge.

Vygotsky, L. (1978). Mind in society: The development of higher psychological process. Cambridge, MA: Harvard University Press.

Wohlwend, K. (2010). A is for avatar: Young children in literacy 2.0 worlds and literacy 1.0 schools. Language Arts, 88(2), 144-152.

Eve Gregory (United Kingdom) is professor emerita of language and culture in education, at Goldsmiths College, University of London. She has worked for over 25 years as an ethnographer with families and communities, focusing on children's language and literacy learning in homes, communities, with siblings and grandparents, and most recently in faith contexts. The Economic and Social Research Council, the Leverhulme Trust, and the Spencer Foundation have supported her work. This work is based in multilingual communities and most takes place in London's East End. She has authored and edited many books, including: City Literacies: Learning to Read Across Generations and Cultures (London: Routledge, 2000) (co-author: A. Williams); On Writing Educational Ethnographies: The Art of Collusion (Stoke-on-Trent, Staff., UK: Trentham, 2005) (co-authors: J. Conteh, C. Kearney, and A. Mor-Sommerfeld); and Learning to Read in a New Language (London and New York, NY: Sage, 2008). 